\title{
Reproductive biology of the sandy shore crab Matuta Iunaris (Brachyura: Calappidae)
}

\author{
O.S. Perez \\ Department of Marine Biology, James Cook University of North Queensland, Townsville, Queensland 4811, Australia
}

\begin{abstract}
Reproduction of an intertidal calappid crab, Matuta lunaris, was studied histologically based on monthly gonad samples from a Queensland, Australia, population between April 1984 and May 1985. Males and females became sexually mature at carapace widths of 43 and $37 \mathrm{~mm}$ respectively. Reproductive activity, as determined from gamete production, mating behaviour and brood incubation, is continuous throughout the year. There was marked asynchrony between individual crabs and no apparent seasonality. Adult females could produce more than one egg batch following the single copulatory event; each egg batch comprised about 65000 eggs.
\end{abstract}

\section{INTRODUCTION}

The reproductive biology of decapod crustaceans is well documented, particularly for brachyurans (reviewed by Sastry 1983). Despite the abundance of literature, however, very little is known of the reproductive biology of the Matutinae (Brachyura: Calappidae), including Matuta lunaris. Previous studies of $M$. lunaris have been limited to observations on reproductive behaviour (Perez \& Bellwood 1989), the incidence of ovigerous females (Pillay \& Nair 1976), and notes on larval development (Rajabai 1959), the latter two being based on populations in India.

Matuta lunaris is a common inhabitant of the surf zone of tropical sandy shores. It has a widespread distribution which extends from the Red Sea to South Africa, Asia and Australia (Chhapgar 1957, Sankarankutty 1962, Guinot 1966, Vannini 1976). In the Great Barrier Reef region, Australia, $M$. lunaris is commonly found in the surf zone of sandy shore beaches on the mainland and some inshore islands (Perez 1986).

Recent studies on the Great Barrier Reef have reported strong seasonal periodicities in the reproductive activity of many invertebrate groups including sponges (Fromont 1988), corals (Harrison et al. 1984, Babcock et al. 1986), polychaetes (Hutchings \& Howitt 1988) and molluscs (Braley 1988, Shelley \& Southgate 1988). Whether the shore invertebrate species in this region show a similar pattern, however, has not been well documented. The aim of this study therefore was to investigate the reproductive biology of Matuta lunaris, a dominant sandy shore species, and to assess whether a similar pattern of seasonality exists. $M$. lunaris is particularly suitable for such a study as it is abundant and easy to obtain, with most size classes present in the surf zone throughout the year. Three aspects of its reproductive biology were investigated: (1) size at sexual maturity, (2) the annual reproductive cycle, and (3) brood size and egg number.

\section{MATERIALS AND METHODS}

Specimens of Matuta lunaris (Forskål) were collected from Pallarenda Beach, Townsville, Australia $\left(19^{\circ} 11.8^{\prime} \mathrm{S}, 146^{\circ} 46.6^{\prime} \mathrm{E}\right)$ between April 1984 and May 1985. All specimens were collected during the midfalling tide, using a $25 \mathrm{~mm}$ mesh, $10 \mathrm{~m} \times 1 \mathrm{~m}$ seine net dragged along the substratum of the surf zone parallel to the shore. Each drag sampled an area of ca $250 \mathrm{~m}^{2}$ All crabs were brought alive to the laboratory for analyses. Each crab was weighed to the nearest $0.1 \mathrm{~g}$ and the carapace width measured to the nearest $0.1 \mathrm{~mm}$. Carapace width is defined as the maximum width of the carapace including the lateral spines. All crabs were dissected within $3 \mathrm{~d}$ of capture.

A preliminary study of the size at sexual maturity based on gonad states was undertaken. In both sexes, a minimum of 5 individuals from each $5 \mathrm{~mm}$ carapace width size class were dissected. The gonads were removed and fixed in Bouin's fluid for $1 \mathrm{wk}$. Fixed gonads were washed in $70 \%$ ethanol, dehydrated and 
cleared in an alcohol-xylene series, embedded in paraffin wax and sectioned at $6 \mu \mathrm{m}$. Sections were stained in Harris haematoxylin and eosin and mounted in synthetic mounting medium (DPX; B.D.H. Chemicals). The histological criterium for sexual maturity in males was defined as the presence of mature sperms in the spermatic ducts of the testis, whilst in females, it was the presence of mature ova in the ovary. Mature gametes were identified following the histological descriptions of other brachyurans (e.g. Portunus sanguinolentus [Ryan 1967a,b] and Chionoecetes opilio [Kon \& Honma 1970a,b]). The size at sexual maturity based on gonad states was expressed as the minimum size at which mature gametes were observed in the gonads.

To investigate the annual reproductive cycle, sampling was carried out at monthly intervals. To avoid any variability in the reproductive states as a result of lunar cycles, all samples were collected within $2 \mathrm{~d}$ of the full moon of each month. The temporal pattern of reproductive activity was determined using a combination of the gonad index method, histological analysis of the testis and ovaries and the incidence of ovigerous females, mating pairs and females with ripe ovaries. A minimum of 10 mature males and 12 mature females were dissected each month, following Boolootian et al. (1959). The gonads were removed and processed following the procedure described above. In addition, the female ovaries were weighed to the nearest $0.001 \mathrm{~g}$ using an electric analytical balance and the gonad index determined following Giese \& Pearse (1974) and Grant \& Tyler (1983a)

In testis sections, the cells within 50 randomly selected lobes in each crab were classified based on the 4 stages of spermatogenic development: spermatogonia, spermatocytes, spermatids and spermatozoa. The percentage of lobes containing a particular cell type were calculated for each individual and the mean frequency calculated for 10 to 12 individuals each month.

In ovarian sections, the sizes of oocytes/ova were measured using an eyepiece graticule calibrated against a stage micrometer. Only those oocytes or ova sectioned through the nucleus were measured. One hundred oocytes and ova were measured in each crab and grouped into 4 size classes based on cell diameter, following the methods of Grant \& Tyler (1983b). The percentage of oocytes in each size class was then calculated for each individual and the mean frequency calculated for 12 individuals each month. As there was a recognizable spent stage in the gonads of female Matuta lunaris, sections of spent ovaries were classified as such, without attempting to measure the oocytes.

Ovigerous females were dissected within $1 \mathrm{~d}$ of capture. The ovaries were removed, weighed and processed following the procedure described above. The egg mass was removed from the abdomen, weighed to the nearest $0.001 \mathrm{~g}$ and its colour noted. Three subsamples were taken, weighed to the nearest $0.001 \mathrm{~g}$ and the number of eggs counted. The mean number of eggs per egg mass was calculated following Fielding \& Haley (1976) and Du Preez \& McLachlan (1984).

Statistical comparisons between months were undertaken using 1-way ANOVAs, following Zar (1974). All percentages were log-transformed prior to testing.

\section{RESULTS}

\section{Size at sexual maturity}

Results are summarized in Table 1 . The smallest sexually mature male was $43.5 \mathrm{~mm}$ carapace width, whilst the smallest sexually mature female was $41 \mathrm{~mm}$ carapace width.

\section{Annual reproductive cycle}

There appears to be no distinct seasonality in the male reproductive cycle. Spermatogonia, spermatocytes, spermatids and mature spermatozoa were consistently found in the lobes of the testis throughout the study period (Fig. 1). Although there was a significant difference between months in the mean number of lobes containing spermatogonia $(\mathrm{F}=4.793 \mathrm{df}=$ $13,119, \mathrm{p}<0.01)$ and spermatids $(\mathrm{F}=2.365, \mathrm{df}=$ $13,119, p<0.05)$, there was no significant difference between months in the mean number of lobes containing spermatocytes $(\mathrm{F}=1.340, \mathrm{df}=13,119, \mathrm{p}>0.05)$ or mature spermatozoa $(F=1.944$, df $=13,119, \mathrm{p}>0.05)$. The frequency of mature males with testes containing mature spermatozoa was relatively high throughout

Table 1 Matuta lunaris. Sizes at sexual maturity based on relative frequency $(\%)$ of individuals dissected with mature gametes in the gonads

\begin{tabular}{|crrrr|}
\hline $\begin{array}{c}\text { Carapace width } \\
\text { (5 mm size classes) }\end{array}$ & No. $\begin{array}{c}\text { Male } \\
\text { Mature } \\
(\%)\end{array}$ & \multicolumn{2}{c|}{$\begin{array}{c}\text { Female } \\
\text { No. }\end{array}$} & $\begin{array}{c}\text { Mature } \\
(\%)\end{array}$ \\
\hline $25.0-29.9$ & 7 & 0 & 5 & 0 \\
$30.0-34.9$ & 5 & 0 & 6 & 0 \\
$35.0-39.9$ & 10 & 0 & 6 & 0 \\
$40.0-44.9$ & 9 & 40 & 15 & 100 \\
$45.0-49.9$ & 8 & 47 & 7 & 100 \\
$50.0-54.9$ & 10 & 83 & 7 & 100 \\
$55.0-59.9$ & 10 & 100 & 6 & 100 \\
$60.0-64.9$ & 5 & 100 & 5 & 100 \\
$65.0-69.9$ & 5 & 100 & no individuals \\
& & & \multicolumn{3}{c}{} \\
\end{tabular}




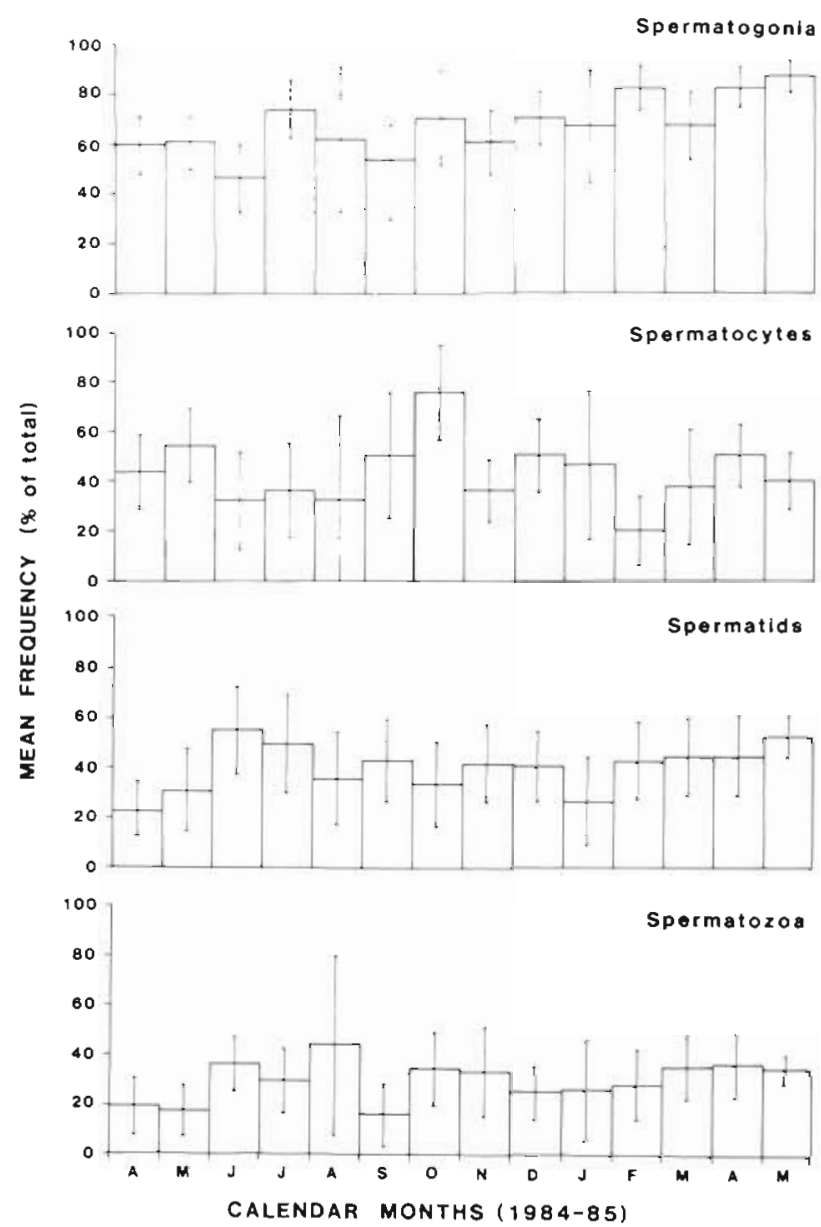

Fig. 1 Matuta lunaris. Summary of relative frequency of male gametogenic cell types each month, expressed as mean percentage of lobes containing each cell type. NB. Lobes often contain more than one cell type. Vertical bars: $95 \% \mathrm{CI}, \mathrm{n}=12$ in all months except September where $n=10$

the study period, ranging from 62.5 to $100 \%$ with a mean of $94.4 \%( \pm 2.45 \%, 95 \% \mathrm{CI})$.

As in male Matuta lunaris, there is no strong seasonality in the female reproductive cycle. Marked ovarian activity was observed in most months of the year, with the single exception of December 1984 where the mean gonad index was relatively low and no mature ova nor females with ripe ovaries were recorded (Figs. 2 and 3). The frequency of ovarian cells measuring 1 to $50 \mu \mathrm{m}$ varied significantly between months $(F=2.240, \mathrm{df}=$ 13.157, $\mathrm{p}<0.02$ ) but the frequencies of oocytes measuring 51 to $100 \mu \mathrm{m}$ and 101 to $150 \mu \mathrm{m}$ did not ( $F=$ 0.915 , df $=13,157, p>0.25$, and $F=0.722, \mathrm{df}=13,157$, $p>0.25$, respectively). Although there was a significant difference between months in the mean gonad indices $(\mathrm{F}=2.239$, $\mathrm{df}=13,157, \mathrm{p}<0.02)$ and in the frequency of mature ova in ovarian sections $(F=1.883$, $\mathrm{df}=13,157, \mathrm{p}<0.05)$, this appeared to be a result of the atypical data in December 1984, as there was no significant difference between the other months (Student-Newman-Keuls, $p>0.05$ ). The percentage of mature females with ripe ovaries varied only slightly throughout the year, with an increase in May and September 1984 and no females with ripe ovaries in December 1984. Ovigerous females were only recorded between August 1984 and March 1985, whilst mating pairs were found in most months of the year. However, no distinct patterns were apparent in either parameter.

In addition, there was no apparent relationship between the mean monthly gonad indices, the frequency of ovigerous females and the frequency of mating pairs. These observations and the large degree of within-sample variability in the individual gonad indices and ovarian cell frequencies each month suggest a lack of reproductive synchrony among individuals in the population.

\section{Biology of ovigerous females}

A total of 26 ovigerous females were collected from the study area between August 1984 and March 1985. The smallest egg-bearing female was $40.7 \mathrm{~mm}$

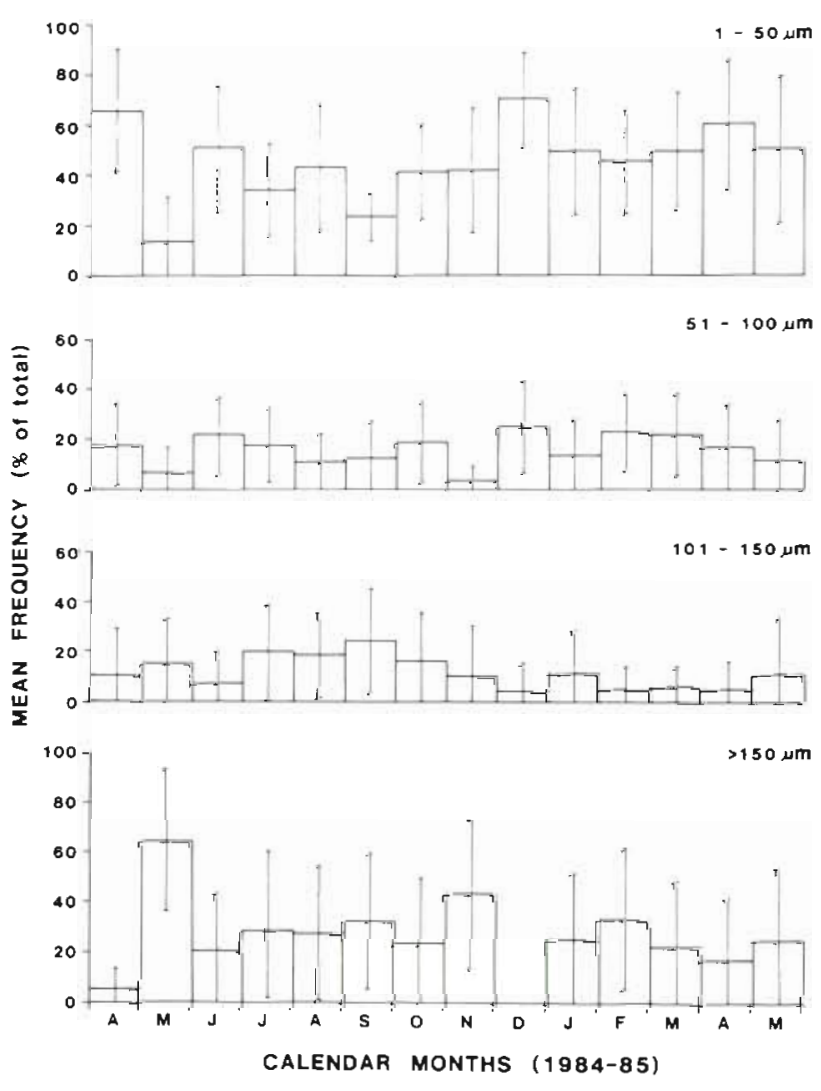

Fig. 2. Matuta lunaris. Summary of relative frequency of ovarian cell sizes each month, expressed as mean percentage of the total number of cells examined in each size class. Vertical bars: $95 \% \mathrm{CI}, \mathrm{n}=12$ in all months 

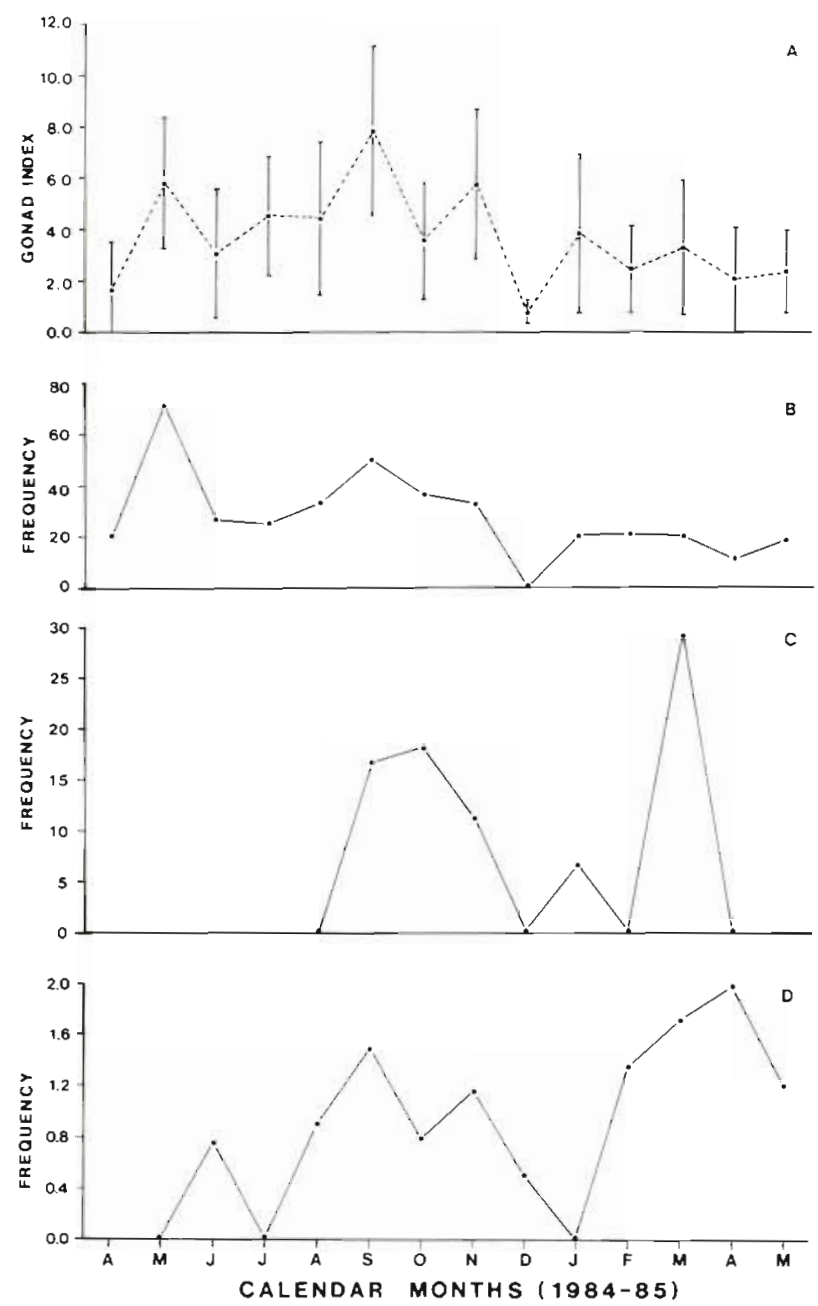

Fig. 3. Matuta lunaris. Annual reproductive activity expressed in terms of: (A) mean monthly female gonad index $\pm 95 \% \mathrm{CI}$ $(\mathrm{n}=12)$; (B) relative frequency of adult femaies with ripe ovaries, expressed as a percentage of the total number of adult females collected per month; (C) relative frequency of ovigerous females, expressed as a percentage of the total number of adult females collected per month; and (D) relative frequency of mating pairs, expressed as a percentage of the total number of crabs collected per month

carapace width. Three stages of brood development were recognized. Stage I, newly laid, Stage II, developing; and Stage III, mature. There was no detectable trend in the occurrence of these brood stages. The results of this study, expressed separately for each of these stages, are summarized in Table 2.

Histologically, it appears that mature females can produce more than one brood. Marked ovarian activity was observed in most ovigerous females with the exception of those with ovaries in the spent phase. In all individuals, oogonia were present in considerable numbers. All the females with Stage II egg masses and $83.3 \%$ of females with Stage III egg masses had ovaries exhibiting advanced stages of vitellogenesis (Table 2).
In addition, all the ovigerous females had spermathecae filled with spermatozoa.

The number of eggs per brood ranged from 40000 to 100000 with a mean of ca 65000 . Although both the number of eggs per brood and the brood weight did not vary significantly with carapace width $(\mathrm{r}=0.0036, \mathrm{~F}=$ $0.0310, \mathrm{p}>0.05$, and $\mathrm{r}=0.0064, \mathrm{~F}=0.0548, \mathrm{p}>0.05$, respectively), a significant difference was found between the mean number of eggs per brood and the stage of development (1-way ANOVA, $F=9.542, \mathrm{df}=$ $2,7, p<0.05)$ with an apparent decrease in the mean number of eggs per brood in Stages II and III egg masses. This may, however, be a result of the limited number of ovigerous females available $(n=10)$. The mean brood weight and egg diameter did not change markedly with development.

\section{DISCUSSION}

\section{Size at sexual maturity}

Results indicate that sexual maturity in Matuta lunaris occurs after the puberty moult. Histologically, the onset of sexual maturity is characterised by the development of gametes in the gonads. In males, this occurs between 40.0 and $50.0 \mathrm{~mm}$ carapace width, whereas in females, it is between 35.0 and $40.0 \mathrm{~mm}$ carapace width. These sizes correspond with sizes at which the puberty moult occurs for each sex (Bellwood \& Perez 1989) and at which sex-related changes in the relative growth of several morphological characters have been observed (e.g. abdomen width; Perez 1986b). It is interesting to note that, for females, the single copulatory event also occurs at this size (Perez \& Bellwood 1989).

\section{Biology of ovigerous females}

There is evidence to suggest that Matuta lunaris females can produce more than one batch of eggs from the single copulatory event. Firstly, the spermathecae of all ovigerous females examined were full of spermatozoa. Sperm storage has been reported in other brachyuran species including Chionoecetes bairdii (Adams \& Paul 1983), Halicarcinus australis (Lucas \& Hodgkin 1970) and Portunus sanguinolentus (Ryan $1967 \mathrm{~b})$. In all cases, the females were observed to produce multiple egg batches within the breeding period without subsequent copulation.

Secondly, marked ovarian activity characterized by high gonad indices and advanced states of vitellogenesis was observed in most ovigerous females. In addition, there was a characteristic proliferation of oogonia and newly formed oocytes into the empty 
Table 2. Matuta lunaris. Observations on the biology of ovigerous females. Mean values are expressed as mean $\pm 95 \% \mathrm{Cl}$

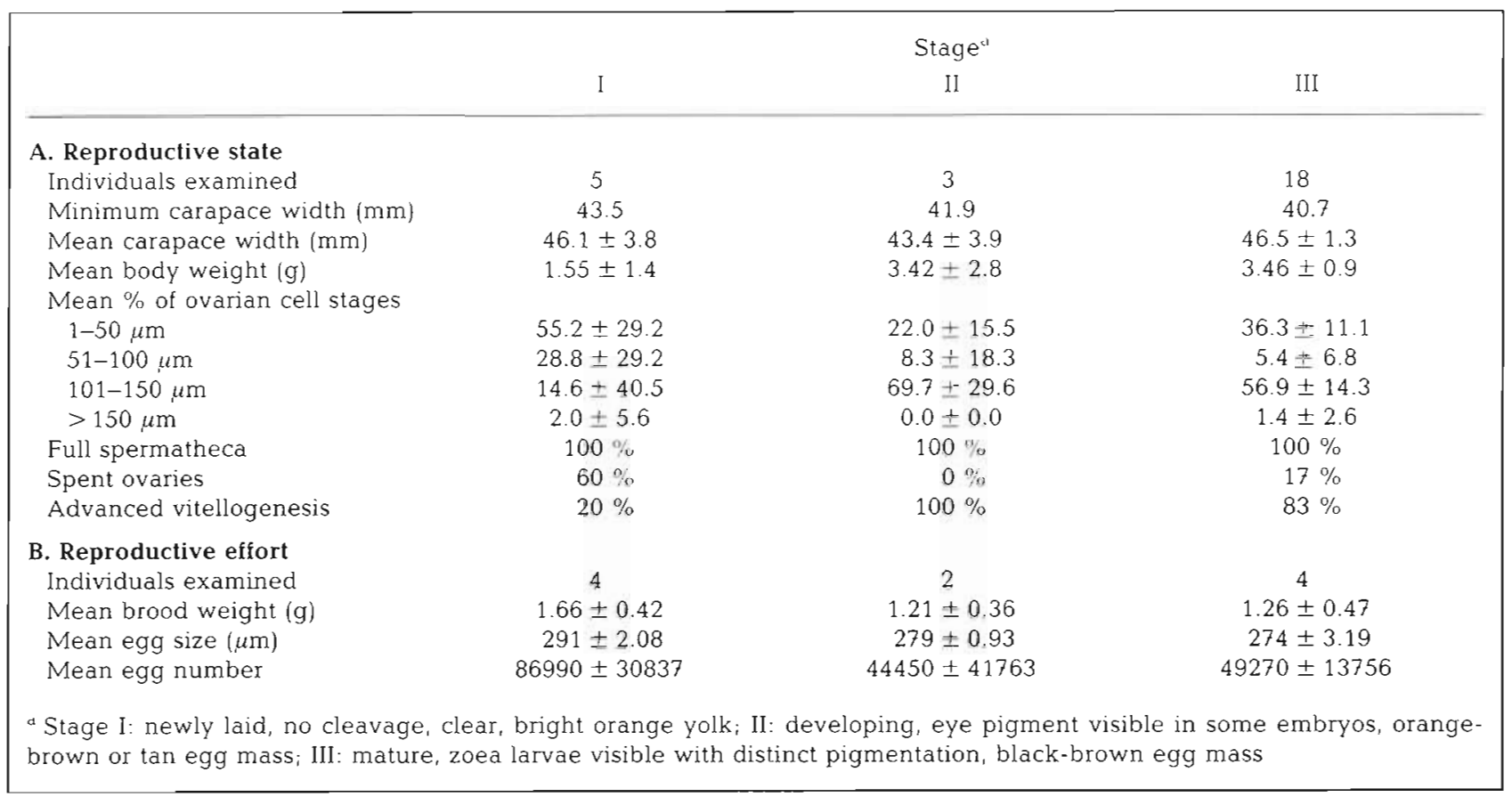

spaces previously occupied by ova in the ovaries of those individuals in the 'spent' phase. The occurrence of ripening ovaries simultaneous with brooded eggs has been reported in other brachyuran species (Ryan 1967b, Pillay \& Nair 1971) and several anomuran species (Ameyaw-Akumfi 1975, Varadarajan \& Subramoniam 1982). This has been interpreted as an indication of the potential to produce a second brood during the same breeding season (Pillay \& Nair 1971).

The number of eggs produced per egg batch by Matuta lunaris varied widely, ranging from 40000 to 100000 eggs with a mean of about 65000 eggs. This is notably higher than the estimated number of eggs per brood recorded from $M$. lunaris in India (1100 to 2580 eggs; Pillay \& Nair 1976). Mean egg diameter, however, was comparable with those recorded by Rajabai (1959) and Pillay \& Nair (1976). The size and number of eggs in $M$. lunaris are consistent with the general observations of Bliss (1968) that swimming crabs and lower intertidal crabs produce a relatively large number of small eggs when compared to other brachyuran species.

\section{Annual reproductive cycle}

The annual reproductive cycle of Matuta lunaris on Pallarenda Beach was continuous, with uninterrupted breeding throughout the year. In males, this was indicated by: (1) the consistent presence of spermatogonia, spermatocytes, spermatids and mature spermatozoa in the lobes of the testes throughout the study period, with no significant difference between months in the mean number of lobes containing spermatocytes or spermatozoa, and (2) the relatively high frequency (>62\%) of mature males with testes containing mature spermatozoa in each month of the year. In females, continuous reproduction was indicated by: (1) marked ovarian activity in most months of the year with no apparent patterns of seasonality in the fluctuations of the gonad indices, (2) the presence of mature females with ripe ovaries in 13 mo of the 14 mo study period, and (3) the presence of mating pairs in most months of the year, with no distinct pattern of seasonality in their occurrence.

Although in the past it was generally believed that tropical invertebrate species breed continuously throughout the year (Semper 1881 in: Pillay \& Nair 1971 , Stephenson 1934, Giese \& Pearse 1974), recent studies have reported seasonal periodicities in the reproductive cycles of many tropical groups such as sponges (e.g. Fromont 1988, Ilan \& Loya 1988), corals (e.g. Harrison et al. 1984, Babcock et al. 1986), polychaetes (e.g. Caspers 1984, Hutchings \& Howitt 1988) and molluscs (e.g. Nagabhushanam \& Deshpande 1982, Braley 1982, 1988). Among the crustaceans, several tropical species have also been reported to demonstrate seasonal reproduction, for example Panulirus argus (Kanciruk \& Herrnkind 1976), Cryptodormia hilgendorfi (McLay 1982), Scylla serrata (Hill 1975) and Portunus pelagicus (Potter et al. 1983). The majority of tropical crustacean species, however, continue to be reported to breed for 
an extended period or even continuously throughout the year. This includes most species of anomurans (Ameyaw-Akumfi 1975, Subramoniam 1979, Varadarajan \& Subramoniam 1982) and many brachyurans (Ryan 1967a,b, Pillay \& Nair 1976, Du Preez \& McLachlan 1984, Gotelli et al. 1985, reviewed by Sastry 1983). Matuta lunaris therefore appears to be a typical tropical brachyuran species in that it demonstrates a continuous reproductive pattern.

It is interesting to note, however, that upon close examination, the reproductive activities of most continuously breeding tropical species often fluctuate to some extent throughout the year. Examples of such species include the hermit crab Clibanarius clibanarius (Varadarajan \& Subramoniam 1982) and the brachyurans Portunus sanguinolentus (Ryan 1967a,b) and Ovalipes punctatus (Du Preez \& McLachlan 1984). In this respect, Matuta lunaris is unusual in that the fluctuations in its reproductive intensity are slight, showing no significant differences between months. This degree of continuity, with no significant differences, has not been demonstrated previously in other brachyuran species.

Finally, it must be noted that whilst the population of Matuta Iunaris from Pallarenda Beach reproduces continuously throughout the year, the breeding pattern of populations of $M$. lunaris in India was reported by Pillay \& Nair (1976) to be seasonal. Such intraspecific variability in the reproductive patterns of geographically separate populations of a single species has been observed in other brachyurans, such as Portunus pelagicus (Rahaman 1967, Ryan 1967a,b, Pillay \& Nair 1971) and Helice crassa (Nye 1977, Jones 1980). These differences have been explained in terms of geographic differences in temperature, salinity and food availability. A study of the environmental factors which determine the reproductive pattern of $M$. lunaris, therefore, would be of considerable interest.

Acknowledgements. The faculty and staff of the Marine Biology Department, James Cook University are gratefully acknowledged for their support, particularly Assoc. Prof. C. G. Alexander for his guidance and encouragement and $\mathrm{Mr} \mathrm{L}$. Winsor for invaluable histological advice. Special thanks are extended to Dr R. G. Hartnoll, Assoc. Prof. J. S. Lucas, Dr N. Holmes and Dr D. R. Bellwood for their constructive comments on various drafts of the manuscript. The valuable comments of 2 anonymous reviewers are gratefully appreciated.

\section{LITERATURE CITED}

Adams, A. E., Paul, A. J. (1983). Male parent size, sperm storage and egg production in the crab Chionoecetes bairdii (Decapoda, Majidae). Int. J. Invert. Reprod. 6: 137-196

Ameyaw-Akumfi, C. (1975). The breeding biology of two sympatric species of tropical, intertidal hermit crabs, Clibanarius chapini and C. senegalensis. Mar Biol. 29: $15-28$
Babcock, R. C., Bull, G. D., Harrison, P. L., Heyward, A. J., Oliver, J. K., Wallace, C. C., Willis, B. L. (1986). Synchronous spawnings of 105 scleractinian coral species on the Great Barrier Reef. Mar. Biol. 90: 379-394

Bellwood, D. R., Perez, O. S. (1989). Sexual differences in the absolute growth pattern of the Indo-Pacific sandy shore crab Matuta lunaris. J. Zool. Lond. 218: 603-608

Bliss, D. (1968). Transition from water to land in decapod crustaceans. Am. Zool. 8: 355-392

Boolootian, R. A., Giese, A. C., Farmanfarmaian, A., Tucker, J. (1959). Reproductive cycles of five west coast crabs. Physiol. Zool. 32: 213-220

Braley, R. D. (1982). Reproductive periodicity in the indigenous oyster Saccostrea crecullata in Sasa Bay, Apra Harbor, Guam. Mar. Biol. 69: 165-173

Braley, R. D. (1988). Reproductive condition and season of the giant clams Tridacna gigas and $T$. derasa utilising a gonad biopsy technique. In: Copland, J. W., Lucas, J. S. (eds.) Giant clams in Asia and the Pacific. ACIAR Monograph No. 9, Canberra, p. 98-103

Caspers, H. (1984). Spawning periodicity and habitat of the palolo worm Eunice virides (Polychaeta: Eunicidae) in the Samoan Islands. Mar. Biol. 79: 229-236

Chhapgar, B. F. (1957). On the marine crabs (Decapoda: Brachyura) of Bombay State. J. Bombay nat. Hist. Soc. 54: 399-439

Du Preez, H. H., McLachlan, A. (1984). Biology of the threespot swimming crab, Ovalipes punctatus (De Haan) III. Reproduction, fecundity and egg development. Crustaceana 47: 285-296

Fielding, A., Haley, S. (1976). Sex ratio, size at reproductive maturity and reproduction of the Hawaiian Kona crab Ranina ranina (Linnaeus) (Brachyura, Gymnopleura, Raninidae). Pacif. Sci. 30: 131-145

Fromont, J. (1988). Aspects of the reproductive biology of Xestospongia testudinaria. Proc. 6th Int. Coral Reef Symp. 2: $685-694$

Giese, A. C., Pearse, J. S. (1974). Introduction: general principles. In: Giese, A. C., Pearse, J. S. (eds.) Reproduction of marine invertebrates, Vol. 1. Academic Press, New York, p. $1-50$

Gotelli, N. J., Gilchrist, S. L., Abele, L. G. (1985). Population biology of Trapezia spp. and other coral-associated decapods. Mar. Ecol. Prog. Ser $21 \quad 89-98$

Grant, A., Tyler, P. A. (1983a). The analysis of data in studies of invertebrate reproduction. I. Introduction and statistical analysis of gonad indices and maturity indices. Int. J. Invert. Reprod. 6: 259-269

Grant, A., Tyler, P. A. (1983b). The analysis of data in studies of invertebrate reproduction. II. The analysis of oocyte size/frequency data, and comparison of different types of data. Int. J. Invert. Reprod. 6: 271-283

Guinot, D. (1966). Les crabes comestibles de l'Indo-Pacifique. Editions del la Foundation Singer-Polignac, Paris

Harrison, P. L., Babcock, R. C., Bull, G. D., Oliver, J. K., Wallace, C C., Willis, B. L. (1984). Mass spawning in tropical reef corals. Science 223: 1186-1187

Hill, B. J. (1975). Abundance, breeding and growth of the crab. Scylla serrata in two South African estuaries. Mar. Biol. 32: 119-126

Hutchings, P., Howitt, L. (1988). Swarming of polychaetes on Great Barrier Reef. Proc. 6th Int. Coral Reef Symp. 2: $739-744$

Ilan, M., Loya, $Y$ (1988). Reproduction and settlement of the coral reef sponge Niphates sp. (Red Sea). Proc. 6th Int. Coral Reef Symp. 2: 745-750 
Jones, M. B. (1980). Reproductive ecology of the estuarine burrowing mud crab Helice crassa (Grapsidae). Estuar. cstl mar. Sci. 11. 433-443

Kanciruk, P., Hernkind, W. F. (1976). Autumnal reproduction in Panulirus argus at Bimini, Bahamas. Bull. mar Sci. 26: $417-432$

Kon, T., Honma, Y (1970a). Studies on the maturity of the gonad in some marine invertebrates. III. Seasonal changes in the ovary of the tanner crab. Bull. Jap. Soc. scient. Fish. 36: 1021-1027

Kon, T., Honma, Y (1970b). Studies on the maturity of the gonad in some marine invertebrates. IV. Seasonal changes in the testes of the tanner crab. Bull. Jap. Soc. scient. Fish. 36: $1028-1033$

Lucas, J. S., Hodgkin, E. P. (1970). Growth and reproduction of Halicarcinus australis (Haswell) (Crustacea, Brachyura) in the Swan Estuary, Western Australia. Aust. J. mar Freshwat. Res. 21: 149-162

McLay, C. L. (1982). Population biology of the sponge crab Cryptodormia hilgendorfi (Dromiacea) in Moreton Bay, Queensland, Australia. Mar Biol. 70: 317-326

Nagabushanam, R., Deshpande, U. D. (1982). Reproductive cycle of the chiton Chiton jatricus and environmental control of its gonad growth. Mar. Biol. 67: 9-13

Nye, P. A. (1977). Reproduction, growth and distribution of grapsid Helice crassa (Dana, 1851) in the southern part of New Zealand. Crustaceana 33: 75-89

Perez, O S. (1986). Studies on the biology of the Indo-Pacific sandy shore crab, Matuta lunaris Forskål (Brachyura: Calappidae). M.Sc, thesis, James Cook University of North Queensland

Perez, O. S., Bellwood, D. R. (1989). Observations on the mating behaviour of the sandy shore crab Matuta lunaris, with notes on the reproductive behaviour of the Matutinae. Crustaceana 57: 1-8

Pillay, K. K., Nair, N. B. (1971). The annual reproductive cycles of Uca annulipes, Portunus pelagicus and Metapenaeus affinis (Decapoda: Crustacea) from the south-west coast of India. Mar. Biol. 11: 152-166

Pillay, K. K., Nair, N. B. (1976). Observations on the breeding biology of some crabs from the southwest coast of India. J. mar. Biol. Ass. India 15: 754-770

Potter, I. C., Chrystal, P. J., Loneragan, N. R. (1983). The

This article was submitted to the editor biology of the blue manna crab Portunus pelagicus in an Australian estuary. Mar Biol. 78: 75-85

Rahaman, A. A. (1967). Reproductive and nutritional cycles of the crab, Portunus pelagicus (Linnaeus) (Decapoda: Brachyura) of the Madras coast. Proc. Indian Acad. Sci. 65: 76-82

Rajabai, K. G. (1959). Development of Calappa lophos (Herbst) and Matuta Lunaris Forskal (Crustacea: Brachyura). J. zool. Soc. India 11. 65-72

Ryan, E. P. (1967a). Structure and function of the reproductive system of the crab Portunus sanguinolentus (Herbst) (Brachyura: Portunidae). I. The male system. Symp. Ser. mar biol. Ass. India 2: 506-521

Ryan, E. P. (1967b). Structure and function of the reproductive system of the crab Portunus sanguinolentus (Herbst) (Brachyura: Portunidae). II. The female system. Symp. Ser mar. biol. Ass. India 2: 522-524

Sankarankutty, C. (1962). On Decapoda Brachyura from the Andaman and Nicobar Islands: 3. Families: Calappidae, Leucosiidae, Parthenopidae, Maiidae and Gecarcinidae. J. mar. biol. Ass. India 4: 151-164

Sastry, A. (1983). Ecological aspects of reproduction. In: Vernberg, F. J., Vernberg, W. (eds.) Biology of Crustacea, Vol. 8. Academic Press, New York, p. 179-270

Shelley, C. C., Southgate, P. C. (1988). Reproductive periodicity and morphometry of Hippopus hippopus and Tridacna crocea. In: Copland, J. W., Lucas, J. S. (eds.) Giant clams in Asia and the Pacific. ACIAR Monograph No. 9, Canberra, p. $86-88$

Stephenson, A. (1934). The breeding of reef animals. Part II. Invertebrates other than corals. Great Barrier Reef Expedition, 1928-29, Scientific Report, Vol. 3. British Museum (Nat. Hist.), p. 219-245

Subramoniam, $T$ (1979). Some aspects of reproductive ecology of a mole crab, Emerita asiatica Milne Edwards. J. exp. mar Biol. Ecol. 36: 256-268

Vannini, M. (1976). Researches on the coast of Somalia. The shore and dune of Sar Uanle. 10. Sandy beach decapods. Monitore zool. ital. (Suppl.) 8: 255-286

Varadarajan, S., Subramoniam, T (1982). Reproduction of the continuously breeding tropical hermit crab Clibanarius clibanarius. Mar. Ecol. Prog. Ser. 8: 197-201

Zar, J. H. (1974). Biostatistical analysis. Prentice-Hall Inc., Englewood Cliffs, NJ

Manuscript first received: February 21, 1989

Revised version accepted: September 16, 1989 